\title{
O Enquadramento Jurisdicional do Esquecimento e o Direito à Memória
}

\section{Tassiana Bezerra dos Santos}

Mestranda em Direito no Programa de Pós-Graduação em Direito da Universidade Federal de Pernambuco (PPGD/ UFPE). Graduada em Direito pela Universidade Católica de Pernambuco (Unicap - 2014.2). tassiana.bezerra@gmail.com

\section{Stéfano Gonçalves Regis Toscano}

Doutor em Direito pela Universidade Federal de Pernambuco (2010). Mestrado em Sociologia pela Universidade Federal da Paraíba (2000). Possui Graduação em Direito pela Universidade Católica de Pernambuco (1994). Professor da Universidade Católica de Pernambuco e da Faculdade Boa Viagem. Em todas as instituições leciona no curso de Graduação em Direito, e na Universidade Católica é professor-colaborador do curso de Mestrado em Direito. stefanotoscano@hotmail.com

\section{Resumo}

A declaração do esquecimento como direito de personalidade pelo STJ abre espaço para uma discussão que está além de um campo puramente jurídico, inclusive a colocação de um debate com 0 direito e até mesmo o dever de memória. Dessa forma, será necessário tratar a memória nos seus aspectos pessoais e coletivos. Neste sentido, o objetivo deste trabalho é demonstrar que a análise de tais questões demanda 0 apoio inequívoco da filosofia.

Palavras-chave: Memória. Esquecimento. Direito. 


\title{
The Judicial Framework of Forgetting and the right to Memory
}

\begin{abstract}
The declaration of forgetfulness as a right of personality by the STJ opens space for a discussion that is beyond a purely juridical field, including the of a debate with the right and even the duty of memory. In this way, it will be necessary to deal with memory in its personal and collective aspects. In this sense, the objective of this work is to demonstrate that the analysis of such questions demands the unequivocal support of philosophy.
\end{abstract}

Keywords: Memory. Forgetting. Law.

Recebido em: 29/5/2017

Revisões requeridas em: 27/9/2017

Aprovado em: 2/12/2017

\section{Sumário}

1 Introdução. 2 Direito ao esquecimento. 2.1 Análise das decisões do Superior Tribunal de Justiça. 3 Memória. 3.1 Memória Individual. 3.2 Memória Coletiva. 3.3 Esquecimento e Memória. 4 Considerações finais. 5 Referências. 


\section{INTRODUÇÃO}

A construção de uma comunidade tem como uma de suas bases a constituição de uma memória coletiva. Fala-se em memória que ultrapassa os limites da pessoalidade; será uma memória atribuída a um grupo, ou seja, construída por meio das ingerências sociais sobre um sujeito.

Nesse sentido, o objetivo deste trabalho é analisar a relação entre direito e memória coletiva a partir das decisões em torno do direito ao esquecimento prolatado recentemente pelo STJ - o Esquecimento -, entendido pela doutrina jurídica como direito inerente à personalidade e norteado pelo princípio da dignidade da pessoa humana. $\mathrm{O}$ estudo em questão, porém, não se limitará a analisar os conceitos de memória ou de esquecimento. A pretensão é, ante a estudos como o de Maurice Halbwachs, relacionar a edificação de uma memória coletiva e as impressões deixadas pela proclamação de um direito que permite e obriga esquecer e ser esquecido. Neste caso, parte-se do princípio de que a composição da memória de um grupo é uma tentativa de imobilizar o tempo e adormecer o esquecimento.

Desta maneira, analisa-se, de acordo com Nietzsche, a necessidade do equilíbrio entre o histórico e o a-histórico para se consolidar a vitalidade de um indivíduo, de um povo e de uma cultura e compreende-se, portanto, a necessidade da história para a vida e para a ação e, consequentemente, dos atos de lembrar e esquecer, dado que este autor considerou absolutamente impossível uma vida sem esquecimento.

Uma vez que o esquecimento intencional e um apagamento de lembranças erguem-se como meios de programar a memória, tanto o ato de rememorar quanto o esquecimento podem ser considerados meios de dominação. Sendo assim, far-se-á necessário entender como a memória 
coletiva pode ser direcionada para a construção de liberdade, bem como para fomentar os abusos das instituições, como do próprio Direito, por intermédio do controle social.

No segmento desta discussão, a ideia é reavaliar questões consideradas de interesse coletivo, como os crimes ocorridos no Holocausto, e reavaliar no sentido de discutir esses temas procurando um equilíbrio diante de uma obrigatoriedade do esquecimento e uma possível obsessão pelo passado. Por conseguinte, procura-se entender, por meio, inclusive, dos depoimentos das vítimas, se existe um real dever de memória ou uma possibilidade efetiva de esquecer, bem como se é possível a prática destas tarefas e qual o papel do direito nesse debate.

\section{DIREITO AO ESQUECIMENTO}

\subsection{Análise das Decisões do Superior Tribunal de Justiça}

O Superior Tribunal de Justiça (STJ), recentemente, discutiu a possibilidade de um direito ao esquecimento, especificamente o impasse entre a liberdade de informação e o direito de esquecer e ser esquecido como inerente à personalidade.

Neste campo, o Judiciário foi instado a resolver os conflitos por demais recorrentes entre a liberdade de informação e de expressão e os direitos inerentes à personalidade, ambos de estatura constitucional. $\mathrm{Na}$ verdade, o mencionado conflito é mesmo imanente à própria opção constitucional pela proteção de valores quase sempre antagônicos, os quais, em última análise, representam, de um lado, o legítimo interesse de "querer ocultar-se" e, de outro, o não menos legítimo interesse de se "fazer revelar" (Resp 1.335.153/RJ, Rel. Ministro LUIS FELIPE SALOMÃO, QUARTA TURMA). 
Um dos casos foi referente ao episódio que ficou conhecido como a Chacina da Candelária, quando policiais à paisana abriram fogo contra cerca de 70 crianças e adolescentes que dormiam nas escadarias da Igreja. Várias ficaram feridas e oito morreram. Três policiais foram condenados pelo crime e dois absolvidos. $\mathrm{O}$ autor da ação foi um dos policiais absolvidos, defendendo que a menção do seu nome no programa Linha Direta da Rede Globo como um dos partícipes do crime, mesmo esclarecendo que ele foi inocentado, causou danos a sua honra e dificultou o seu convívio social. O outro caso diz respeito ao crime contra Aída Curi, estuprada e morta em 1958 por um grupo de jovens. Os familiares da vítima afirmaram que reviver essa história, por meio do mesmo programa transmitido na emissora, trouxe à tona a dor e a angústia da família pelo fato passado.

Nos dois casos analisados foi proclamado o direito ao esquecimento, ainda que no segundo caso o relator tenha entendido que ali não cabia o direito ao esquecimento. A principal causa enunciada foi a época atual de hiperinformacionismo, quando a informação é imediata e ultrapassa os limites da vida privada, da intimidade e do próprio tempo. Logo, a Constituição Federal defende a liberdade de informação e manifestação do pensamento, mas o faz com certas diretrizes e limites, confirmando que os direitos e garantias defendidos ali não são absolutos. Por conseguinte, a dignidade da pessoa humana torna-se um fundamento pelo qual devem ser interpretados os demais direitos. Além disso, durante os dias 11 e 12 de março de 2013 ocorreu a VI Jornada de Direito Civil promovida pelo Conselho de Justiça Federal e, dentre os enunciados aprovados, destaca-se o de número 531, que trouxe a discussão em torno do Direito ao Esquecimento.

ENUNCIADO 531 - A tutela da dignidade da pessoa humana na sociedade da informação inclui o direito ao esquecimento. Artigo: 11 do Código Civil Justificativa: Os danos provocados pelas novas tecnologias de informação vêm-se acumulando nos dias atuais. $\mathrm{O}$ direito ao esquecimento tem sua origem histórica no campo das condenações 
criminais. Surge como parcela importante do direito do ex-detento à ressocialização. Não atribui a ninguém o direito de apagar fatos ou reescrever a própria história, mas apenas assegura a possibilidade de discutir o uso que é dado aos fatos pretéritos, mais especificamente o modo e a finalidade com que são lembrados.

O esquecimento, assim sendo, ocupa o rol de direitos inerentes à personalidade, norteado pelo princípio da dignidade da pessoa humana, sendo este basilar para o sistema constitucional brasileiro.

Faz-se necessário compreender a ideia de personalidade como uma capacidade jurídica para ter direitos e deveres. Segundo o civilista Caio Mário da Silva Pereira, a personalidade tem um sentido universal, logo todos os seres humanos serão capazes de direitos e deveres na ordem civil, inclusive sem que dependa da consciência ou da vontade do indivíduo: "A personalidade, como atributo da pessoa humana, está a ela indissoluvelmente ligada. Sua duração é a vida” (PEREIRA, 2014, p. 183).

Entendimento sedimentado também pelo Código Civil Brasileiro de 2002 em seu artigo 11º. "Com exceção dos casos previstos em lei, os direitos da personalidade são intransmissíveis e irrenunciáveis, não podendo o seu exercício sofrer limitação voluntária”.

Ou seja, a personalidade jurídica no direito brasileiro possui dois requisitos: o nascimento e a vida. A partir do momento do nascimento se constituirá uma pessoa com direitos e obrigações. Ainda segundo Caio Mário, antes disso o que existem são direitos em potencial. É neste ramo do direito que o esquecimento está incluso. Após a jornada de direito civil e as decisões do Superior Tribunal de Justiça, a possibilidade de esquecer e ser esquecido se corporifica no ordenamento jurídico brasileiro como um direito inerente à pessoa.

Para fundamentar tal entendimento nas decisões do STJ, o direito ao esquecimento deve ser enxergado sob a ótica da proteção à dignidade da pessoa humana. Esta é considerada um dos princípios fundamentais na 
Constituição Federal, sendo, inclusive, colocada por Inocêncio Mártires Coelho como um valor pré-constituinte, o qual funciona como eixo para as disposições legais constitucionais.

A introdução explícita, contudo, da ideia de direito ao esquecimento, possibilita inúmeras controvérsias, entre elas o conflito entre este e outros direitos de estatura constitucional. Necessariamente, o conflito se dá no domínio contraditório entre o direito e a memória coletiva, por que incide no tratamento seletivo sobre os eventos registrados no passado da sociedade brasileira, fato posto em discussão na própria decisão do tribunal superior: "O direito de fazer desaparecer as informações que retratam uma pessoa significa perda da própria história, o que vale dizer que o direito ao esquecimento afronta o direito à memória de toda a sociedade”.

Pelo que foi exposto, compreende-se a necessidade de analisar tais decisões a partir, também, de um viés teórico, no sentido de investigar os próprios conceitos de memória e esquecimento para, assim, criticar o manuseio jurídico desses institutos.

\section{MEMÓRIA}

\subsection{Memória Individual}

Ao longo de uma tradição de pensamento no ocidente foi imputada à memória uma dimensão meramente subjetiva. Isto é, ao sujeito caberia a permanente relação com o seu passado, registrando certa causalidade de eventos. As imagens do passado seriam formadas subjetivamente.

No percurso da memória oferecido por Paul Ricoeur (2007) em A Memória a História o Esquecimento, é possível ver essa clara ligação da Memória com a construção de imagens a partir de Platão. Com este filósofo explica-se a memória a partir da ideia de que há um bloco de cera em nossas almas que imprime as percepções e pensamentos de quando 
vemos, ouvimos ou pensamos em algo, como um anel que deixa sua marca. Para Platão, cada cera é de uma qualidade diferente, dependendo do indivíduo, por isso cada imagem será gravada de forma diversa e cada memória será também diversa.

Pois bem, concede-me propor, em apoio ao que tenho dizer, que nossas almas contêm em si um bloco maleável de cera: maior em alguns, menor em outros, de uma cera mais pura para uns, mais impura para outros, e bastante dura, mas mais úmida para alguns, havendo aqueles para quem ela está no meio-termo. - Teeto: Concedo. - Sócrates: Pois então, digamos que se trata de um dom da mãe das Musas, Memória: exatamente como quando, à guisa de assinatura, imprimimos a marca de nossos anéis, quando pomos esse bloco de cera sob as sensações e os pensamentos, imprimimos nele aquilo que queremos recordar, quer se trate de coisas que vimos, ouvimos ou recebemos no espírito. $\mathrm{E}$ aquilo que foi impresso, nós o recordamos e 0 sabemos, enquanto a sua imagem (eidolon) está ali, ao passo que aquilo que é apagado ou aquilo que não foi capaz de ser impresso, nós esquecemos (epilelesthai), isto é, não o sabemos (PLATÃO apud RICOEUR, 2007, p. 28).

Neste sentido, Ricoeur compreende que a questão da memória em Platão é a "representação presente de uma coisa ausente" e, portanto, estaria no campo da imaginação. É necessário também observar que Platão elucida quanto à questão do esquecimento quando se refere àquilo que não foi impresso ou foi apagado posteriormente, demonstrando a relação indiscutível entre memória e esquecimento.

Tratando ainda de uma herança grega, Aristóteles (2012) traz em Da Memória e da Reminiscência, a noção de memória como parte da alma e da imaginação. Assim, constitui dois caminhos dentro do campo mnemônico: a evocação simples e o esforço de recordação. O primeiro como uma lembrança que vem ao espírito naturalmente e o segundo como um resgate de conhecimento do interior do indivíduo por meio de uma sucessão de atos; não que o ato de recordar fosse, para Aristóteles, menos natural, mas seria necessário, neste caso, um porto de partida. 
Como Paul Ricoeur nos recorda, foi John Locke quem colocou como fundamento único da identidade pessoal a experiência que cada indivíduo tem de si mesmo. De acordo com Locke, a identidade de uma pessoa se estende tão longe quanto à consciência de si pode se estender sobre as ações ou os pensamentos já passados. Desse modo, é baseado em uma consciência de si e os diferentes momentos de sua experiência que cada um se representa e constitui a unidade de seu próprio ser; é a partir da memória de si mesmo no passado que o indivíduo se conhece como sendo o mesmo de um tempo a outro, bem como de um lugar a outro.

Desde os estudos do sociólogo Maurice Halbwachs, contudo, articulou-se uma mudança na observação das estruturas mnemônicas: "A memória foi pensada a partir dos laços sociais existentes entre indivíduos constituídos no presente” (SANTOS, 2012, p. 26). Logo, a memória passou a ser observada enquanto uma construção coletiva por intermédio de formas de registros socialmente instituídas.

[...] nossas lembranças permanecem coletivas, e elas nos são lembradas pelos outros, mesmo que se trate de acontecimentos nos quais só nós estivemos envolvidos, e com objetos que só nós vimos. É porque, em realidade, nunca estamos sós. Não é necessário que outros homens estejam lá, que se distingam materialmente de nós: porque temos sempre conosco e em nós uma quantidade de pessoas que não se confundem (...) Para que nossa memória se auxilie com a dos outros, não basta que eles nos tragam seus depoimentos: é necessário ainda que ela não tenha cessado de concordar com suas memórias e que haja bastante pontos de contato entre uma e outras para que a lembrança que nos recordam possa ser reconstruída sobre um fundamento comum (HALBWACHS, 2013, p. 26-34).

A memória constitui o espaço social e este constitui a memória. Excede-se o lastro simplesmente mental. A capacidade de rememorar está objetivada nas representações, rituais, textos, festas comemorativas. Nesse sentido, constata-se o paradoxo da memória: “é fundamental com- 
preender que a memória é sempre sujeito e objeto do conhecimento" (SANTOS, 2012, p. 30-31). A cada prática social no presente carrega-se a herança do passado construída na interpretação do presente. Halbwachs afirmou que indivíduos se lembravam do passado ao se colocarem sob a perspectiva do grupo, e o que importava mostrar era que a memória do grupo se realizava e manifestava-se nas memórias individuais; ainda, que indivíduos se recordam de acordo com estruturas sociais que os antecedem.

De bom grado, diríamos que cada memória individual é um ponto de vista sobre a memória coletiva, que este ponto de vista muda segundo o lugar que ali ocupo e que esse mesmo lugar muda segundo as relações que mantenho com outros ambientes (...) A sucessão de lembranças, mesmo as mais pessoais, sempre se explica pelas mudanças que se produzem em nossas relações com os diversos ambientes coletivos, ou seja, em definitivo, pelas transformações desses ambientes, cada um tomado em separado, e em seu conjunto (HALBWACHS, 2013, p. 69).

Assim, entende-se a impossibilidade de uma memória puramente individual, posto que todas as lembranças são construídas pelas relações com os grupos aos quais os indivíduos pertencem. A memória, conhecida como individual, será, então, a zona de união das variadas influências exercidas sobre o sujeito.

\subsection{Memória Coletiva}

A partir da proposição da existência da memória de um grupo, influenciando, inclusive, o que se conhece como memória individual, se faz necessário aprofundar o real sentido de memória coletiva. 
Não se pode compreender a edificação de uma memória coletiva como simples construção da história, um narrar/escrever os fatos. Logo, diferencia-se a memória social do que se poderia intitular de memória histórica - segundo Halbwachs, esta expressão não é muito feliz por associar dois termos que se opõem em vários pontos.

Se, por memória histórica, entendemos a sequiência de eventos cuja lembrança a história conserva, não será ela, não serão seus contextos que representam o essencial disso que chamamos de memória coletiva (HALBWACHS, 2013, p. 99).

Maurice Halbwachs entende que a história se constrói quando a memória coletiva se desfaz, pois, enquanto persistir uma lembrança, será dispensável fixá-la por escrito. Dentro da história engendra-se o aniquilamento da memória espontânea.

A necessidade de escrever a história de um período, de uma sociedade e até mesmo de uma pessoa só desperta quando elas já estão bastante distantes no passado para que ainda se tenha por muito tempo a chance de encontrar em volta diversas testemunhas que conservam alguma lembrança. Quando a memória de uma sequiência de acontecimentos não tem mais por suporte um grupo, o próprio evento que nele esteve envolvido ou que dele teve consequiências, que a ele assistiu ou dele recebeu uma descrição ao vivo de atores e espectadores de primeira mão - quando ela se dispersa por alguns espíritos individuais, perdidos em novas sociedades que não se interessam mais por esses fatos que lhe são decididamente exteriores, então o único meio de preservar essas lembranças é fixá-los por escrito em uma narrativa, pois os escritos permanecem, enquanto as palavras e os pensamentos morrer (HALBWACHS, 2013, p. 101).

Ainda que a função da História seja criar uma ligação entre o passado e o futuro, tal fato não se constitui enquanto memória, uma vez que existirá uma lacuna entre os grupos que leem essa História e os que a 
testemunharam e são capazes de mantê-la viva. Neste sentido, enquanto a história retém os fatos para contar, a intenção de construir uma memória coletiva não é, senão, manter o que é vivente na percepção de um grupo.

A primeira diferença a se constatar é a continuidade de uma memória coletiva ante os recortes em períodos, séculos feitos pela História. Enquanto a História vai oferecer uma construção lógica e artificial do passado, a memória de uma sociedade vai alcançar somente o que ela pode, mantendo-se presente unicamente nos grupos que a sustentam. Sendo assim, não se pode mensurar exatamente a duração da memória de um conjunto, pois é difícil pontuar o desaparecimento de uma lembrança coletiva. Se a memória persiste em uma parte do que representa o corpo social de um grupo e ali consegue ser recuperada, não se pode falar em esquecimento, porque, como Pierre Nora coloca, a memória é a vida e está sempre aberta ao debate da lembrança e do esquecimento. Tal fato a configura como contínua, uma vez que no processo de rememoração não há espaço para intervalos.

É importante salientar que Michel Foucault (2008), em A Arqueologia do Saber, chama a atenção não somente para as divisões de séculos ou épocas elaboradas pela História, mas também para a descontinuidade.

Sob as grandes continuidades do pensamento, sob as manifestações maciças e homogêneas de um espírito ou de uma mentalidade coletiva, sob o devir obstinado de uma ciência que luta apaixonadamente por existir e por se aperfeiçoar desde seu começo, sob a persistência de um gênero, de uma forma, de uma disciplina, de uma atividade teórica, procura-se agora detectar a incidência das interrupções, cuja posição e natureza são, aliás, bastante diversas (FOUCAULT, 2008, p. 4).

Assim, Foucault pretende desconstruir a concepção de uma História como memória milenar e coletiva. A História é a elementar utilização de documentos materiais que fazem permanecerem determinados fatos, e estes documentos não arquitetam a memória de uma sociedade. 
O documento não é o feliz instrumento de uma história que seria em si mesma, e de pleno direito, memória: a história é, para uma sociedade, uma certa maneira de dar status e elaboração à massa documental de que ela não se separa (FOUCAULT, 2008, p. 8).

Além disso, de acordo com Halbwachs, a História é una, busca reproduzir um único percurso da humanidade, ainda que se fale em História da Europa ou da América, enquanto existem muitas memórias coletivas, pois um único indivíduo fará parte de inúmeros grupos e construirá diversas lembranças referentes a cada conjunto distinto, como família, escola, amigos.

Nesta discussão é primordial perceber como a constituição do esquecimento como direito pode ir de encontro à própria edificação de uma memória social, tendo em vista que o ato de esquecer institucionalizado pode representar a construção de uma identidade coletiva artificial.

\subsection{Esquecimento e Memória}

Compreende-se o esquecimento como um direito de personalidade resguardado pelo ordenamento jurídico brasileiro com base no respeito ao princípio da dignidade da pessoa humana. Necessário se faz, porém, aprofundar o conceito de esquecimento que ultrapassa os limites estritamente jurídicos, mas que não elimina sua influência sobre o direito, principalmente o direito enquanto articulador social e político. Assim, o campo jurídico se tornará, aqui, um meio pelo qual serão institucionalizados e controlados o esquecimento e a memória social. Dessa forma, até aqui demonstrada, é perceptível que o direito, historicamente, se apropria de noções que ultrapassam o campo comum de atuação do direito, então essas noções devem ser discutidas além da dogmática, portanto no campo também da filosofia. 
Para isso ocorrer, Friedrich Nietzsche é fundamental, considerando o esquecimento como uma força plástica que um homem, um povo ou uma cultura possui. É pelo tamanho dessa força que se sabe a capacidade de um ser de curar feridas ou de superar uma injustiça. Logo, segundo Nietzsche (2003), a superação de fatos passados e a boa vivência somente ocorrerão com a possibilidade de esquecer: "Portanto: é possível viver quase sem lembrança, sim, e viver feliz assim, como o mostra o animal; mas é absolutamente impossivel viver, em geral, sem esquecimento”.

Neste caminho, Nietzsche (2003) trabalhará com a importância da história e do esquecimento, bem como da indispensabilidade de um equilíbrio entre estes dois momentos, pois entende que há um grau de utilização da História que se torna desnecessário e danoso para uma sociedade. Este sentido histórico será a mesma memória histórica diferenciada da memória coletiva por Halbwachs, compreendendo, aqui, esta última enquanto formação natural e espontânea, o que não impede que em um dado momento social seja necessária a formação de uma memória como meio de resistência.

A História foi considerada um meio de guardar e de se estar sempre ligado a determinados fatos, dificultando, assim, o esquecimento. Enquanto o animal vive a-historicamente, porque tem, de acordo com Nietzsche (2003), o privilégio de esquecer, o homem lembra e vive de maneira demasiadamente histórica, apegado a lembranças e ao passado como um todo. É nesse modo de vida histórico que o homem deve ser crítico e fazer uso da história em prol da vida. É somente nesta harmonia entre esquecer e lembrar que o homem se torna homem, como também é no excesso da História que o homem deixa de ser de homem: "Mas que a vida necessite da história precisa ser tão claramente concebido quanto à formulação que precisará ser posteriormente demonstrada - que um excesso de história prejudica o vivente”. 
Para tornar possível este equilíbrio no homem, Nietzsche (2003) vai utilizar três aspectos históricos que são reflexos de três espécies de História. A primeira espécie é a monumental, que diz respeito ao vivente quando ele age e aspira, a segunda categoria de História é a chamada de antiquária, neste caso pertinente ao homem no momento em que ele preserva e venera, e a terceira natureza da História é a que Nietzsche (2003) intitula crítica, aqui, é cabível ao homem que sofre e carece de libertação.

A História monumental será utilizada quando tratar de fatos considerados grandiosos, que merecem permanecer vivos pela sua superioridade diante dos demais acontecimentos. Ou seja, neste viés histórico importa as grandes batalhas, os heróis, os homens poderosos e, assim, vive-se a contemplação de um passado grandioso. Ainda que esse caminho traga ao homem um orgulho, uma crença na sua capacidade de também protagonizar um fato importante, o problema de considerar um entendimento histórico na vida somente pelo seu sentido monumental é arriscado, pois serão privilegiadas partes do passado enquanto outros segmentos cairão no esquecimento. Se o passado for considerado somente algo digno de admiração haverá grande possibilidade de ser distorcido e se tornar uma mentira, uma vez que será dotado de qualidades que, muitas vezes, não possuía.

A história monumental ilude por meio de analogias: através de similitudes sedutoras, ela impele os corajosos à temeridade, os entusiasmados ao fanatismo. E se imaginarmos esta história nas mãos e cabeças de egoístas talentosos e salafrários exaltados, então impérios podem ser destruídos, príncipes assassinados, guerras e revoluções podem ser provocadas e a quantidade de "efeitos em si" históricos, isto é, de efeitos sem uma causa suficiente, aumenta de novo (NIETZSCHE, 2003, p. 22-23).

Quando Nietzsche utiliza como exemplo o caráter monumental, ele quer demonstrar que qualquer espécie de História utilizada em um momento não propício abala o compromisso com a vida. 
Assim, aquele que pretende cuidar do antigo se comportará como um historiador antiquário, que olha para trás com fidelidade e nostalgia. Nesta espécie de História, o homem toma para si, por exemplo, a História da sua cidade no sentido mais objetivo, desde sua formação física até as manifestações populares. Ele usa um entendimento que vai além do individual e constrói sua História a partir de uma História coletiva, fazendo uso também da afetividade. Aqui, é perceptível que a construção de uma memória coletiva necessita, em certa medida, desse olhar antiquário para que se queira preservar um fato específico, pois, como colocou Halbwachs (2013), a memória de um grupo depende dessa interação com o meio e com os objetos.

O homem antiquário tem, porém, muitas vezes, uma visão limitada do passado, pois, pelo seu desejo de venerar, acaba conferindo a tudo que existiu uma grande importância sem que haja um exame de proporcionalidade. Assim, aplaude-se tudo que é passado e antigo e hostiliza-se o novo, o futuro. Deste modo, assim como a memória social pode se pautar do aspecto antiquário da História, este é também o seu desafio, uma vez que, nas palavras de Nietzsche (2003), o homem que idolatra o que passou sem críticas, não mais conserva a vida, mas a mumifica. A produção de uma memória coletiva se faz necessária muito menos para manter vivo um passado do que para vislumbrar a possibilidade de um porvir melhor. A memória entra em cena não apenas para conservar a História, mas para gerá-la, o que não é possível com um excesso de História antiquária.

Não de maneira diferente, a História crítica deverá ser utilizada na situação oportuna, portanto, quando um homem precisar analisar a importância de um fato para que ele perdure na sua vida e em um contexto social, ou seja, deixado ao esquecimento. Neste sentido, um homem que lida com um sofrimento do passado precisa manusear a necessidade de esquecer com o dever de rememorar; logo este sujeito aplicará a História crítica, que julga e condena. É aqui que o equilíbrio entre o histórico e o 
a-histórico deve prevalecer: “[...] e somente aquele que tem o peito oprimido por uma necessidade atual e que quer a qualquer preço se livrar do peso em suas costas carece de uma história crítica, isto é, de uma história que julga e condena”.

No uso da História crítica para atingir este equilíbrio, Nietzsche defende a necessidade de levar o passado a julgamento e condená-lo, tendo em vista que em todo passado sempre houve violência. Para ele, isso vai até além da justiça; é a vida que anuncia o veredicto, que, por querer se manter, necessita do esquecimento como forma de sentenciar o passado. Esta mesma vida ávida por esquecimento, no entanto, precisa, por vezes, esquecer o esquecimento para construir uma História de maneira crítica e, assim, uma memória coletiva.

Aqui fica claro o quão necessariamente o homem, ao lado do modo monumental e antiquário de considerar o passado, também precisa muito freqüentemente de um terceiro modo, o modo crítico: e, em verdade, este também uma vez mais a serviço da vida (NIETZSCHE, 2003, p. 29).

Neste sentido, o esquecimento é o caminho capaz de evitar um retorno sempre ao mesmo ponto, impedindo um engessamento do passado. Em algumas situações, porém, o passado precisa ser confrontado, e não somente pelas pessoas que lá estavam como também por aqueles que o carregam como heranças, pois, segundo Nietzsche, não apenas somos resultado das gerações anteriores como somos também os seus herdeiros e, neste papel, é necessário ir de encontro ao passado de aberrações para se construir algo novo, ainda que este novo venha a se constituir como velho um dia.

Pois porque somos o resultado de gerações anteriores, também somos o resultado de suas aberrações, paixões e erros, mesmo de seus crimes, não é possível se libertar totalmente desta cadeia. Se condenamos aquelas aberrações e nos consideramos desobrigados em relação 
a elas, então o fato de provirmos delas não é afastado. O melhor que podemos fazer é confrontar a natureza herdada e hereditária com o nosso conhecimento, combater através de uma nova disciplina rigorosa o que foi trazido de muito longe e o que foi herdado, implantando um novo hábito, um novo instinto, uma segunda natureza, de modo que a primeira natureza se debilite (NIETZSCHE, 2003, p. 30-31).

Na segunda dissertação de Genealogia da Moral, Nietzsche fala de uma vontade de memória (ou memória da vontade) como uma oposição que o homem criou ao esquecimento. Para ele, não é mais um não poder esquecer e sim um não querer esquecer. Esta vontade de rememorar, todavia, somente se constituirá por meio da dor; apenas aquilo que ainda causa sofrimento fica na memória. Ou seja, se houve a necessidade de se criar uma memória é porque ali houve martírio.

Inclusive, aqui é interessante recorrer à ideia de Platão sobre memória, supracitada, para explicar como o campo mnemônico pode estar ligado a fatos traumáticos. Pode-se utilizar a metáfora do bloco de cera para explicar um trauma, uma vez que, segundo Platão, cada indivíduo tem a cera com características específicas. Neste sentido, um bloco de cera um pouco menos úmido que o normal pode não receber da forma apropriada a impressão deixada por um fato. Como dito anteriormente, $o$ anel imprime sua marca na cera, porém o bloco pode não resistir à força daquela impressão e "quebrar". Da mesma forma, o ser humano pode não saber lidar com as consequências de determinado fato e recalcá-lo, deixando-o escondido.

Jeanne Marie Gagnebin, ao comentar a obra de Aleida Assmann, fala sobre o poder do trauma na memória de um indivíduo:

O "trauma" é a ferida aberta na alma ou no corpo por acontecimentos violentos, recalcados ou não, mas que não conseguem ser elaborados simbolicamente, em particular lingüisticamente, pelo sujeito. Ora, depois das duas Guerras Mundiais e, sobretudo, depois da Shoah (Catástrofe, em hebraico), a temática do trauma torna-se predominante. 
Parece que as feridas continuam abertas, que não podem ser curadas, nem por encantações, nem por narrativas. A ferida não cicatriza e o viajante, quando, por sorte, consegue voltar para algo como uma "pátria", não tem nem as palavras para contar, nem os ouvintes afetuosos para escutá-lo (GAGNEBIN, 2002, p. 127).

Segue-se a ideia nietzschiana bem como a noção de trauma para compreender o medo do esquecimento em casos de crimes contra a humanidade, como o Holocausto, pois, ao tratar de memória e esquecimento enquanto possível atuação do direito, é fundamental ocupar-se da análise de tais fatos, uma vez que estes crimes confrontam diretamente as noções de lembrar e esquecer e a própria ideia de justiça.

Primo Levi (2013), ao narrar os horrores por ele sofridos em Auschwitz, responde a qualquer dúvida que pode haver quanto à conveniência de guardar tal situação humana na memória com a convicção de que é necessário. Ele afirma que, por pior que seja, o campo de concentração foi uma experiência biológica e social e, por isso, pode construir valores fundamentais, ainda que nem sempre positivos. O depoimento de Primo Levi exibe a pertinência do uso da história de maneira crítica, sem que o esquecimento seja utilizado com a desculpa de seguir em frente para viver bem, como um empecilho para a construção de uma memória social pautada em experiências anteriores.

Giorgio Agamben, em $O$ que resta de Auschwitz (2008), analisa os depoimentos de Primo Levi. O autor inicia seu estudo tratando do que faria um deportado ao campo sobreviver e o posterior ato de testemunhar, de relatar o que aconteceu ali. Ainda que Agamben não considere um efetivo dever de memória, algumas das pessoas que estiveram naquela situação acreditam que o seu encargo é nunca deixar que tais fatos caiam no esquecimento; “que a testemunha morra”. É bem verdade que Agamben observa na testemunha muito menos uma informação do que uma lacuna, pois, segundo ele, o campo de concentração, o paradigma do 
espaço político contemporâneo, constrói horrores inenarráveis. Logo, o testemunho dos sobreviventes declara a impossibilidade de sua completa autenticidade, pois aquilo que compõe a sua narrativa não é o essencial do que ocorreu nos campos, pois este foge à própria linguagem, porém, ainda que incompleto, deve ser relatado. Há que se lembrar que esta é uma ideia que deixa dúvidas, pois o que se pode considerar inenarrável? $\mathrm{O}$ que se vivenciou lá não se pode narrar ou não se pode fazer com que os ouvintes sintam o que o sobrevivente sentiu? Estas são questões que levam a outras discussões. O que não se pode negar é a importância do relato, do ato de contar, falar, escrever. O importante era "voltar, comer, contar o que aconteceu”. Ou seja, a necessidade de contar aos outros passa a competir com outras necessidades essenciais.

Primo Levi não está, com isso, querendo o eterno retorno de Auschwitz, pois, para ele, aquilo nunca deixou de acontecer, e continua fazendo parte dele em forma de angústia. Bem como em É isto um homem? (2013) quando ele relata que, enquanto estava no campo, uma de suas maiores aflições era um sonho que tinha frequentemente, no qual estava com a sua família e alguns amigos e começava a contar tudo que havia se passado enquanto prisioneiro. Seu terror começava, porém, quando percebia que as pessoas que ali estavam não se interessavam pelo fato descrito. Depois de um tempo, Primo Levi descobriu que este sonho não pertencia somente a ele; outros judeus deportados contaram que tal situação também fazia parte dos seus sonhos. É o medo de que os outros não se importassem com o que estava ocorrendo ali.

Aqui está minha irmã, e algum amigo (qual?), e muitas outras pessoas. Todos me escutam, enquanto conto do apito em três notas, da cama dura, do vizinho que gostaria de empurrar para o lado, mas tenho medo de acordá-lo porque é mais forte do que eu. Conto também a história da nossa fome, e do controle dos piolhos, e do Kapo que me deu um soco no nariz e logo mandou que me lavasse porque sangrava. É uma felicidade interna, física, inefável, estar em minha casa, entre pessoas 
amigas, e ter tanta coisa para contar, mas bem me apercebo de que eles não me escutam. Parecem indiferentes; falam entre si de outras coisas, como se eu não estivesse. Minha irmã olha para mim, levanta, vai embora em silêncio (LEVI, 2013, p. 85).

Lili Jaffe, outra deportada a Auschwitz, após a guerra, escreveu um diário sobre o que ocorreu no campo, publicado posteriormente com comentários da sua filha Noemi Jaffe. Em muitas partes do texto ela defende um esquecimento ou uma morte da memória como forma de viver, afirmando que a lembrança torna a vítima da dor passada uma nova vítima destas lembranças. Para ela, o esquecimento não é um vazio e sim um espaço preenchido com imagens e palavras que não falam. Neste sentido, o esquecido é o que estaria não somente fora da memória, mas também fora da linguagem, do discurso, quando se fala em um esquecimento não espontâneo, programado.

Ainda, todavia, que defendam o esquecimento, quando pensam sobre o sentido de ainda se escrever sobre o Holocausto, uma vez que a literatura sobre o assunto é tão vasta, tanto Lili Jaffe quanto Noemi Jaffe não conseguem deixar clara a motivação, mas sabem que precisam expor essa História, ainda que seja mais uma, para tardar o desaparecimento, para diminuir as chances de que Auschwitz se torne apenas mais uma palavra. Quando a filha pergunta à mãe porque ela escreveu o diário, a mãe responde que foi para que a filha soubesse da História.

Esta é mais uma história que se perde no mar de histórias de sobreviventes, todas elas únicas. Não há motivações claras. As motivações são obscuras e a filha e a mãe sentem que elas precisam ser expostas: para que elas aprendam alguma coisa, para que elas conheçam sua memória e seu esquecimento, para que a micro história da mãe receba um lugar inscrito no corpo do mundo. As palavras podem ser a memória que ela perdeu; não somente porque é através delas que se conta a narrativa, mas porque elas, em si mesmas, fixam minimamente algo cuja tendência natural é desaparecer (JAFFE, 2012, p. 185). 
Com relação a não possibilidade do esquecimento dos crimes contra a humanidade, em Poder e Desaparecimento (2013) Pilar Calveiro analisa o significado político do campo de concentração para trazê-lo numa analogia à ditadura argentina. Ao ponderar sobre tais relações, Calveiro aborda mais do que as condições desumanas que existiram nas duas situações; ela adentra também às razões de sobrevivência de um preso político, como ela, na ditadura. E, seguindo as declarações de inúmeras vítimas do Holocausto, Pilar Calveiro revela que havia uma obsessão nos campos argentinos - a necessidade de sobreviver para contar os fatos - e, nesse ponto específico, em relativa oposição a Agamben, construir, efetivamente, uma memória sobre o terror vivenciado.

O depoimento de Pilar Calveiro, assim como o sonho de Primo Levi ou as lembranças e deslembranças de Lili Jaffe, demonstram a apreensão de que tais fatos sejam esquecidos. Isso, porém, vai além do simples esquecimento como um direito de personalidade, ainda que defendido como meio de proteção à dignidade humana. $\mathrm{O}$ direito não pode e não consegue esgotar esta questão. $\mathrm{O}$ julgamento que decide pelo esquecimento não traz consigo a busca pela verdade e pela justiça. Mais do que o julgamento e, até mesmo a condenação como no caso de Nuremberg, a memória se faz importante para fazer pensar Auschwitz e, aqui, uso este campo de extermínio como um paradigma. Nesse sentido, o domínio jurídico passa pela construção de dispositivos de controle da relação entre memória, liberdade e esquecimento. A justiça de uma sociedade somente é possível na medida em que o direito ao esquecimento também gera um direito à memória.

\section{CONSIDERAÇÕES FINAIS}

Pelo que foi exposto, o que se quer ponderar é a tomada de espaços pelo direito que antes pertenciam à seara íntima do indivíduo ou de determinados grupos. As decisões do Superior Tribunal de Justiça definem o 
que fica ou não na memória de uma sociedade a partir de um processo seletivo do que pode ser considerado privado ou de interesse coletivo. Assim, vê-se uma forma de esquecimento comandado, institucionalizado. Emoldura-se o esquecimento e a memória, limitando e ordenando os seus espaços.

É necessário compreender que esta possibilidade de declarar o esquecimento como direito abre um caminho sem volta que permite a criação de novas formas de narrar as histórias, da maneira que for mais conveniente naquele momento. Ou seja, está criada a condição para que o direito determine e edite as narrativas de cada indivíduo, de cada grupo. Este recurso é uma armadilha e, mais uma vez, nas palavras de Ricoeur (2007): "Está em ação aqui uma forma ardilosa de esquecimento, resultante do desapossamento dos atores sociais de seu poder originário de narrarem a si mesmos”.

Nesta discussão, entretanto, é primordial aclarar a própria expressão direito à memória para não recair na mesma insídia dos usos do esquecimento. Por mais que possa se falar em um dever de memória sobre alguns fatos, como foi anteriormente discutido, não se pode permitir a defesa de um direito à memória que também classifica, seleciona e obriga.

O direito à memória se constituirá, justamente, na oposição ao apagamento do passado, proposto pelo esquecimento. A ideia é abrir-se para ele e elaborá-lo por meio da situação histórica. Dessa forma, percebe-se que a memória vai além da norma. Mariana Pimentel Fischer Pacheco esclarece a sua importância:

A amplitude e a dimensão social do questionamento leva à compreensão de que o direito à memória não deve ser pensado de maneira intransigente. É a formação atual de uma comunidade que poderá mostrar qual o tempo da lembrança e se há, no momento, preparação à necessária elaboração (2009, p. 267). 
Entende-se que o tempo da lembrança ou do esquecimento tem de ser definido além do alcance jurídico. $\mathrm{O}$ direito não pode recontar a História social sem que haja consequências.

Os depoimentos dos sobreviventes dos campos de concentração demonstram, no mesmo sentido colocado por Nietzsche e supraexplicado, que a decisão de julgar e condenar o passado pertence antes à vida, à sociedade; portanto, vai além do direito.

\section{REFERÊNCIAS}

AGAMBEN, G. O que resta de Auschwitz: o arquivo e a testemunha (Homo Sacer III). São Paulo: Boitempo, 2008.

ARISTÓTELES. Parva Naturalia. Tradução Edson Bini. São Paulo: Edipro, 2012.

BRANCO; Paulo Gustavo Gonet; COELHO, Inocencio Martires; MENDES, Gilmar Ferreira. Curso de Direito Constitucional. São Paulo: Saraiva, 2013.

BRASIL. Conselho da Justiça Federal. Enunciado 531. IV Jornada de Direito Civil. Disponível em: <www.cjf.jus.br/cjf/CEJ-Coedi/jornadas-cej/vijornada. pdf $>$. Acesso em: 12 set. 2013.

Superior Tribunal de Justiça. Recurso Especial n. 1.334.097. Quarta Turma, Rel. Min. Luis Felipe Salomão. Julgamento em 28/5/2013.

. Superior Tribunal de Justiça. Recurso Especial n. 1.335.153. Quarta Turma, Rel. Min. Luis Felipe Salomão. Julgamento em 28/5/2013.

CALVEIRO, P. Poder e desaparecimento: os campos de concentração na Argentina. São Paulo: Boitempo, 2013.

FOUCAULT, M. A arqueologia do saber. Rio de Janeiro: Forense Universitária, 2008.

GAGNEBIN, Jeanne Marie. Lembrar escrever esquecer. Rio de Janeiro. Editora 34, 2006. 
O rastro e a cicatriz: metáforas da memória. Revista Pro-Posições, v. 13, p. 125-133, 2002.

HALBWACHS, M. A memória coletiva. São Paulo: Centauro, 2013.

JAFFE, N. O que os cegos estão sonhando? Rio de Janeiro: Editora 34, 2012.

LEVI, P. É isto um homem? Rio de Janeiro: Rocco, 2013.

NIETZSCHE, F. Genealogia da moral: uma polêmica. São Paulo: Companhia das Letras, 2009.

Segunda consideração intempestiva: da utilidade e desvantagem da história para a vida. Rio de Janeiro: Relume Dumará, 2003.

PACHECO, Mariana Pimentel Fischer. Direito à memória como exigência ética: uma investigação a partir da hermenêutica filosófica de Hans-Georg Gadamer. Revista Anistia Política e Justiça de Transição, Brasília, v. 1, p. 250269, 2009.

PEREIRA, Caio Mário da Silva. Instituições de Direito Civil. 27. ed. Rio de Janeiro: Forense, 2014. V. 1.

RICOEUR, P. A memória, a história, o esquecimento. Campinas, SP: Ed. da Unicamp, 2007.

SANTOS, M. S. Memória coletiva e teoria social. São Paulo: Annablume, 2012. 